medRxiv preprint doi: https://doi.org/10.1101/2022.02.06.22270457; this version posted February 8,2022 . The copyright holder for this preprint (which was not certified by peer review) is the author/funder, who has granted medRxiv a license to display the preprint in All rights reserved. No reuse allowed without permission.

\title{
Protection of COVID-19 vaccination and previous infection against Omicron BA.1 and Delta SARS- CoV-2 infections, the Netherlands, 22 November 2021- 19 January 2022
}

Stijn P. Andeweg ${ }^{1}$, Brechje de Gier ${ }^{1}$, Dirk Eggink ${ }^{1}$, Caroline van den Ende ${ }^{1}$, Noortje van Maarseveen ${ }^{2,3}$, Lubna Ali ${ }^{2}$, Boris Vlaemynck ${ }^{4}$, Raf Schepers ${ }^{4}$, RIVM COVID-19 surveillance and epidemiology team, Susan J.M. Hahné ${ }^{1}$, Chantal Reusken ${ }^{1}$, Hester E. de Melker ${ }^{1}$, Susan van den Hof $^{1}$, Mirjam J. Knol ${ }^{1}$

Author affiliations:

${ }^{1}$ Center for Infectious Disease Control, National Institute for Public Health and the Environment (RIVM), Bilthoven, the Netherlands

${ }^{2}$ Saltro Diagnostic Center for Primary Care, Utrecht, The Netherlands.

${ }^{3}$ Department of Medical Microbiology, University Medical Center Utrecht, Utrecht, the Netherlands

${ }^{4}$ SYNLAB, Heppignies, Belgium

\section{Abstract}

Given the emergence of the SARS-CoV-2 Omicron BA.1 variant and the roll-out of booster COVID-19 vaccination, evidence is needed on protection conferred by primary vaccination, booster vaccination and previous SARS-CoV-2 infection against Omicron BA.1 compared with Delta infection.

We employed a test-negative design and used multinomial logistic regression on data from community PCR testing in the Netherlands, from 22 November 2021 to 19 January 2022. S-gene target failure (SGTF) was used as proxy for Omicron BA.1 infection versus Delta.

A total of 528,488 tests were included, of which 38,975 SGTF and 41,245 non-SGTF infections. Protection from primary vaccination was $33 \%$ (95\% confidence interval (CI): $31-35$ ) and from previous infection 25\% (95\% Cl: 21-29) against Omicron BA.1 infection. Protection against Delta infection was higher with $76 \%$ (95\% Cl: 75-76) for primary vaccination and $78 \%$ (95\% Cl: 76-80) for previous infection. Higher protection was observed in individuals with both primary vaccination and earlier infection compared with either one. Waning of vaccine- or infection-induced protection over time was observed against both variants. Booster vaccination considerably increased vaccine effectiveness against Omicron BA.1 to $76 \%$ (95\% Cl: 72-79) and 68\% (95\% Cl: 67-69) with and without previous infection, respectively.

Primary vaccination with current COVID-19 vaccines and pre-Omicron SARS-CoV-2 infections offer low protection against Omicron BA.1 infection. Booster vaccination considerably increases protection against Omicron BA.1, although protection remains lower than against Delta.

\section{Background}

Since November 2021 the Omicron BA.1 SARS-CoV-2 variant (Nextclade 21K, Pango lineage B.1.1.529/BA.1) has rapidly spread causing high numbers of infections across Europe, due to higher transmissibility and immune escape of this variant [1]. In the Netherlands, the Omicron variant was first detected end of November 2021 [2]. Several studies suggest Omicron causes less severe disease, also when adjusted for infection- and vaccine-induced immune status [3-5]. However, this benefit for public health can possibly be outweighed by large numbers of infections and result in iAEREE 
medRxiv preprint doi: https://doi.org/10.1101/2022.02.06.22270457; this version posted February 8,2022 . The copyright holder for this preprint (which was not certified by peer review) is the author/funder, who has granted medRxiv a license to display the preprint in All rights reserved. No reuse allowed without permission.

In vitro assays have shown largely reduced neutralisation of the Omicron variant with convalescent sera or sera of vaccinated individuals [6]. Early studies on vaccine effectiveness showed very limited protection of primary COVID-19 vaccination against Omicron infection [7]. Booster vaccination increases protection, although to a smaller extent than against Delta. Also, protection seems to wane rapidly [8]. The rate of reinfections with Omicron is larger than seen with other variants, indicating that previous infections with another variant do not provide sufficient protection against Omicron $[9,10]$. The level of protection against infection induced by the combination of vaccination and previous infection is largely unknown. Vaccine effectiveness against severe disease seems to be better preserved and restored to around $90 \%$ shortly after booster vaccination [8].

The Dutch COVID-19 vaccination program started in January 2021, first targeting residents of longterm care facilities and health care workers, and then following an age-dependent roll out starting with the oldest. At the end of summer 2021, all persons of 12 years and older had had the opportunity to complete primary vaccination. The coverage of full primary vaccination was $86 \%$ in January 2022 in adults 18 years or older [11]. In November 2021, the booster vaccination campaign started in the Netherlands. On January $132022,50 \%$ of the adult population had received a booster vaccination [11]. Comirnaty (BNT162b2, BioNTech/Pfizer, 77\% of primary vaccination doses), Spikevax (mRNA-1273, Moderna, 8\%), Vaxzevria (ChAdOx1, AstraZeneca, 11\%) and Janssen vaccine (4\%) have been used for primary vaccination in the Netherlands [12]. Comirnaty (49\% of all booster doses) and Spikevax (51\%) have been used for booster vaccination.

Recently we showed with a case-only design that infection- and vaccine-induced protection of the primary series was much reduced for Omicron BA.1 infection compared with Delta [9]. Here we use a test-negative design to estimate the effects of primary and booster vaccination and previous infection on the protection against Omicron BA.1 infections compared with Delta, during the period when both variants circulated in the Netherlands. S-gene target failure (SGTF) was used as a proxy for Omicron BA.1 infection. We assess the effectiveness of primary and booster vaccination, with and without previous infections, by time since vaccination or previous infection and by age group, on the odds of testing positive for Omicron or Delta. To this end, we employed data from 528,488 community-based SARS-CoV-2 tests performed between November 22, 2021 and January 19, 2022.

\section{Methods}

\section{Study population}

Data with a sample date between 22 November 2021 and 19 January 2022 from two large diagnostic laboratories were used, which analyse specimens from national community testing in the Netherlands that make use of the TaqPath COVID-19 RT-PCR Kit (ThermoFisher Scientific). This PCRkit tests for three targets (S, ORF1ab and N). S-gene target failure (SGTF) in combination with a proper signal from ORF1ab and N, also referred to as S-drop-out has proven to be a highly specific proxy for Omicron BA.1 in this time period [9]. With lower viral loads, the S-gene target tends to be less sensitive and therefore only results with a Ct value of $\leq 30$ for the ORF1ab and $\mathrm{N}$ targets were included for further analyses. A proper signal in all three targets is a proxy for the Delta variant. Although Omicron BA. 2 would also result in signal in all three targets as this variant lacks the deletion in the spike gene, this variant had only been sporadically observed in The Netherlands during the study period [2].

From 1 June 2020 onwards, mass testing for SARS-CoV-2 organized by the 25 regional Public Health Services (PHS) has been available for Dutch citizens experiencing COVID-19 like symptoms or who 
medRxiv preprint doi: https://doi.org/10.1101/2022.02.06.22270457; this version posted February 8,2022 . The copyright holder for this preprint (which was not certified by peer review) is the author/funder, who has granted medRxiv a license to display the preprint in All rights reserved. No reuse allowed without permission.

have been in contact with someone testing positive for SARS-CoV-2. Individuals with a positive result on a self-administered rapid antigen test were also urged to seek confirmation PCR testing. When a test is requested, a questionnaire is taken including questions on COVID-19 vaccination status. Test results from the two laboratories were linked to the national community testing register (CoronIT), containing pseudonymized data with demographic characteristics and vaccination status. We excluded tests performed to confirm a positive self-administered antigen test, and persons with a positive test 30 days before the current test to avoid including multiple tests of the same episode. Persons with unknown immune status were also excluded. Of persons testing more than once during the study period, either the first positive test (if any positive test during the study period) or the last negative test was included in the analysis to only include one test per person.

\section{Immune status definitions}

Previous infection was defined as a positive test by PCR or antigen test at the PHS testing locations at any time point between 1 June 2020 and 30 days before the current test included in the study. Primary vaccination was defined as having received two doses of Comirnaty (BNT162b2, BioNTech/Pfizer), Spikevax (mRNA-1273, Moderna) or Vaxzevria (ChAdOx1, AstraZeneca) more than 14 days before the symptom onset date or one dose of Janssen vaccine more than 28 days before the symptom onset date. The questionnaire included the number of doses received, and the date and vaccine brand of the last dose received. Booster vaccination was defined as having received a third dose at least 7 days before symptom onset, if the date of last vaccination was after 18 November 2021 (the start of the booster vaccination campaign in the Netherlands). For cases without a reported onset date, sample date minus two days was used (two days is the median time between onset date and sample date for persons in which onset data is known). Persons that did not receive any vaccine were defined as unvaccinated.

Immune status was defined using a combination of vaccination status and previous infection status. "Naive" was defined as unvaccinated without a known previous infection. "Previous infection, unvaccinated" was unvaccinated with at least one previous infection. "Primary vaccination" was a completed primary vaccination series without known previous infection. "First infection, then primary vaccination" was defined as a previous infection where the self-reported number of vaccine doses received at the time of previous infection was zero. "First start primary vaccination, then infection" was defined as a previous infection where the self-reported number of vaccine doses received at the time of previous infection was at least one. Because the booster vaccination campaign was rolled out during the study period, all persons with "Previous infection, booster" can be assumed to have had a previous infection before receipt of the booster vaccine. Tests for which the immune status could not be placed in any of these categories were excluded. Immune status was further stratified into time since last event, which pertains to the date of last vaccination or the sampling date of the positive test.

\section{Statistical analysis}

We compared immune status between persons testing positive for Delta or Omicron BA.1 (based on SGTF) and persons testing negative. We performed multinomial logistic regression with immune status as the independent variable and test result (negative as reference level, positive for Delta, positive for Omicron) as the independent variable, adjusting for testing date (as natural cubic spline with 4 degrees of freedom), 5 -year age group and sex. We calculated the relative reduction of odds of a positive test result, with immune status "naïve" as reference, after vaccination (i.e. vaccine effectiveness) and previous infection as (1-OR)*100. 
medRxiv preprint doi: https://doi.org/10.1101/2022.02.06.22270457; this version posted February 8, 2022. The copyright holder for this preprint (which was not certified by peer review) is the author/funder, who has granted medRxiv a license to display the preprint in All rights reserved. No reuse allowed without permission.

Children $<18$ years of age were excluded from the main analysis comparing all immune statuses, because they were not yet eligible for (booster) vaccination in the study period. For the analyses stratified by age group, children $<18$ years old were included to assess the protective effect of previous infection on Delta and Omicron infection and, for 12-17 years old, to assess effectiveness of primary vaccination.

\section{Results}

Between 22 November 2021 and 19 January 2022, 1,238,163 samples were tested at one of the two diagnostic laboratories that performed SGTF-PCR. After exclusions, 528,488 tests were included in the analysis (Figure S1). Of these, 448,268 (84.8\%) were negative, $41,245(7.8 \%)$ were positive for Delta and 38,974 (7.4\%) were positive for Omicron (Table 1). Among positive cases, the proportion of SGTF increased from $0.1 \%$ on 24 November 2021 to $95.4 \%$ on 19 January 2022, with an earlier increase in the 12-29 age group (Figure S2).

Previous infection, primary vaccination or both protected well against a Delta infection, with a relative reduction between 76\% (95\% confidence interval (Cl): 75-76) and 95\% (95\% Cl: 94-95) (Table 2). Booster vaccination increased the protection against Delta infection to $93 \%$ (95\% Cl: 93-94), or 97\% (95\% Cl: 94-98) in persons with also a previous infection. Protection of a previous infection or primary vaccination was much lower against an Omicron BA.1 infection, with relative reductions of $25 \%$ (95\% Cl: $21-29)$ and $33 \%$ (95\% Cl: $31-35$ ) after previous infection or primary vaccination, respectively. Persons who had received primary vaccination and had a previous infection were better protected (58-62\%) than only primary vaccination or only previous infection. The sequence of vaccination and infection seemed not to have a large effect on the level of protection. Booster vaccination increased protection against Omicron BA.1 infection to $68 \%$ (95\% Cl: 67-70), or 76\% (95\% Cl: 72-79) in persons with also a previous infection, but it was remarkably lower than against a Delta infection. The relative reduction of booster vaccination against Omicron BA.1 infection compared with primary vaccination was $53 \%$ (95\% Cl: $51-55 \%)$ for persons without a previous infection and $38 \%$ (95\% Cl: $29-46 \%$ ) for persons with a previous infection.

Protection against both Delta and Omicron BA.1 infection waned with time since primary vaccination or infection (Figure 1). For Omicron BA.1 infection, the relative reduction decreased from $40-50 \%$ shortly after primary vaccination or infection to $15-30 \%$ at 30 weeks or more after primary vaccination or infection. For Delta infection, the relative reduction decreased from $85 \%$ to $70 \%$ over time since primary vaccination or infection. Also in persons with both primary vaccination and previous infection, waning of protection was observed by time since vaccination or infection. The protection shortly after booster vaccination was comparable to protection shortly after a combination of primary vaccination and infection (60-70\%).

Protection conferred by previous infection against Omicron BA.1 was higher for children 0-11 and 12-17 compared to persons aged $18-59$, especially for Omicron BA.1 ( $44 \%$ and $37 \%$ vs $22 \%$, p for interaction $<0.001$ and 0.015 , respectively) (Figure 2 ). The effectiveness of primary vaccination decreased with increasing age for both variants, although the estimate for Omicron BA.1 in those aged 60 years and older had a wide confidence interval. A previous infection after the start of a primary vaccination series conferred more protection with increasing age ( $p$ for interaction $<0.001$ ), especially for Omicron, although confidence intervals are wide. 
medRxiv preprint doi: https://doi.org/10.1101/2022.02.06.22270457; this version posted February 8, 2022. The copyright holder for this preprint (which was not certified by peer review) is the author/funder, who has granted medRxiv a license to display the preprint in All rights reserved. No reuse allowed without permission.

Table 1. Characteristics of persons testing negative for SARS-CoV-2, testing positive for Delta SARSCoV-2 (S-gene target detected), and testing positive for Omicron BA.1 SARS-CoV-2 (S-gene target not detected), $n=528,487$, the Netherlands, 22 November 2021 - 19 January 2022

\begin{tabular}{|c|c|c|c|c|c|c|c|}
\hline & & \multicolumn{2}{|c|}{ Negative } & \multicolumn{2}{|l|}{ Delta } & \multicolumn{2}{|c|}{ Omicron BA.1 } \\
\hline & & $\mathrm{n}$ & $\%$ & $\mathrm{n}$ & $\%$ & $\mathrm{n}$ & $\%$ \\
\hline Total & & 448268 & 100 & 41245 & 100 & 38975 & 100 \\
\hline \multirow[t]{5}{*}{ Age } & $0-11$ & 77496 & 17.3 & 9336 & 22.6 & 4601 & 11.8 \\
\hline & $12-17$ & 41909 & 9.3 & 2479 & 6.0 & 4671 & 12.0 \\
\hline & $18-29$ & 86299 & 19.3 & 5735 & 13.9 & 11729 & 30.1 \\
\hline & $30-59$ & 187272 & 41.8 & 17475 & 42.4 & 15618 & 40.1 \\
\hline & $60+$ & 55292 & 12.3 & 6220 & 15.1 & 2356 & 6.0 \\
\hline \multirow[t]{2}{*}{ Sex } & Female & 239892 & 53.5 & 20689 & 50.2 & 20296 & 52.1 \\
\hline & Male & 208376 & 46.5 & 20556 & 49.8 & 18679 & 47.9 \\
\hline \multirow{7}{*}{$\begin{array}{l}\text { Immune } \\
\text { status }\end{array}$} & Naive & 127867 & 28.9 & 21774 & 52.9 & 12862 & 33.3 \\
\hline & $\begin{array}{l}\text { Previous } \\
\text { infection, } \\
\text { unvaccinated }\end{array}$ & 19972 & 4.5 & 705 & 1.7 & 2368 & 6.1 \\
\hline & $\begin{array}{l}\text { Primary } \\
\text { vaccination }\end{array}$ & 232493 & 52.5 & 18092 & 43.9 & 17672 & 45.8 \\
\hline & Booster & 42932 & 9.7 & 343 & 0.8 & 4186 & 10.8 \\
\hline & $\begin{array}{l}\text { First start } \\
\text { primary } \\
\text { vaccination, } \\
\text { then infection }\end{array}$ & 5579 & 1.3 & 91 & 0.2 & 485 & 1.3 \\
\hline & $\begin{array}{l}\text { First infection, } \\
\text { then primary } \\
\text { vaccination }\end{array}$ & 10871 & 2.5 & 157 & 0.4 & 770 & 2.0 \\
\hline & $\begin{array}{l}\text { Previous } \\
\text { infection, } \\
\text { booster }\end{array}$ & 3319 & 0.7 & 11 & 0.0 & 264 & 0.7 \\
\hline \multirow{5}{*}{$\begin{array}{l}\text { Last } \\
\text { received } \\
\text { vaccine }\end{array}$} & Comirnaty & 220779 & 49.3 & 13920 & 33.7 & 17498 & 44.9 \\
\hline & Spikevax & 42956 & 9.6 & 1341 & 3.3 & 3530 & 9.1 \\
\hline & Vaxzevria & 18543 & 4.1 & 2038 & 4.9 & 723 & 1.9 \\
\hline & Janssen & 18151 & 4.0 & 1467 & 3.6 & 1994 & 5.1 \\
\hline & None & 147839 & 33.0 & 22479 & 54.5 & 15230 & 39.1 \\
\hline
\end{tabular}

Table 2. Relative reduction in Delta and Omicron BA.1 infections after previous infection, primary vaccination, booster vaccination, or combinations of previous infection and vaccination, compared with naïve status $(1-O R * 100)$ in persons aged 18 and older.

\begin{tabular}{|l|l|l|}
\hline \multicolumn{1}{|c|}{ Immune status } & \multicolumn{1}{|c|}{$\begin{array}{c}\text { Relative reduction }(\mathbf{9 5 \%} \mathrm{Cl}), \\
\text { Delta }\end{array}$} & $\begin{array}{c}\text { Relative reduction }(\mathbf{9 5 \%} \mathrm{Cl}), \\
\text { Omicron BA.1 }\end{array}$ \\
\hline Naive & Reference & Reference \\
\hline
\end{tabular}


medRxiv preprint doi: https://doi.org/10.1101/2022.02.06.22270457; this version posted February 8,2022 . The copyright holder for this preprint (which was not certified by peer review) is the author/funder, who has granted medRxiv a license to display the preprint in

All rights reserved. No reuse allowed without permission.

\begin{tabular}{|l|l|l|}
\hline $\begin{array}{l}\text { Previous infection, } \\
\text { unvaccinated }\end{array}$ & $78 \%(76-80)$ & $25 \%(21-29)$ \\
\hline Primary vaccination & $76 \%(75-76)$ & $33 \%(31-35)$ \\
\hline Booster & $93 \%(93-94)$ & $68 \%(67-70)$ \\
\hline $\begin{array}{l}\text { First start primary } \\
\text { vaccination, } \\
\text { then infection }\end{array}$ & $91 \%(89-93)$ & $62 \%(58-66)$ \\
\hline $\begin{array}{l}\text { First infection, } \\
\text { then primary vaccination }\end{array}$ & $95 \%(94-95)$ & $58 \%(55-61)$ \\
\hline $\begin{array}{l}\text { Previous infection, } \\
\text { booster }\end{array}$ & $97 \%(94-98)$ & $76 \%(72-79)$ \\
\hline
\end{tabular}

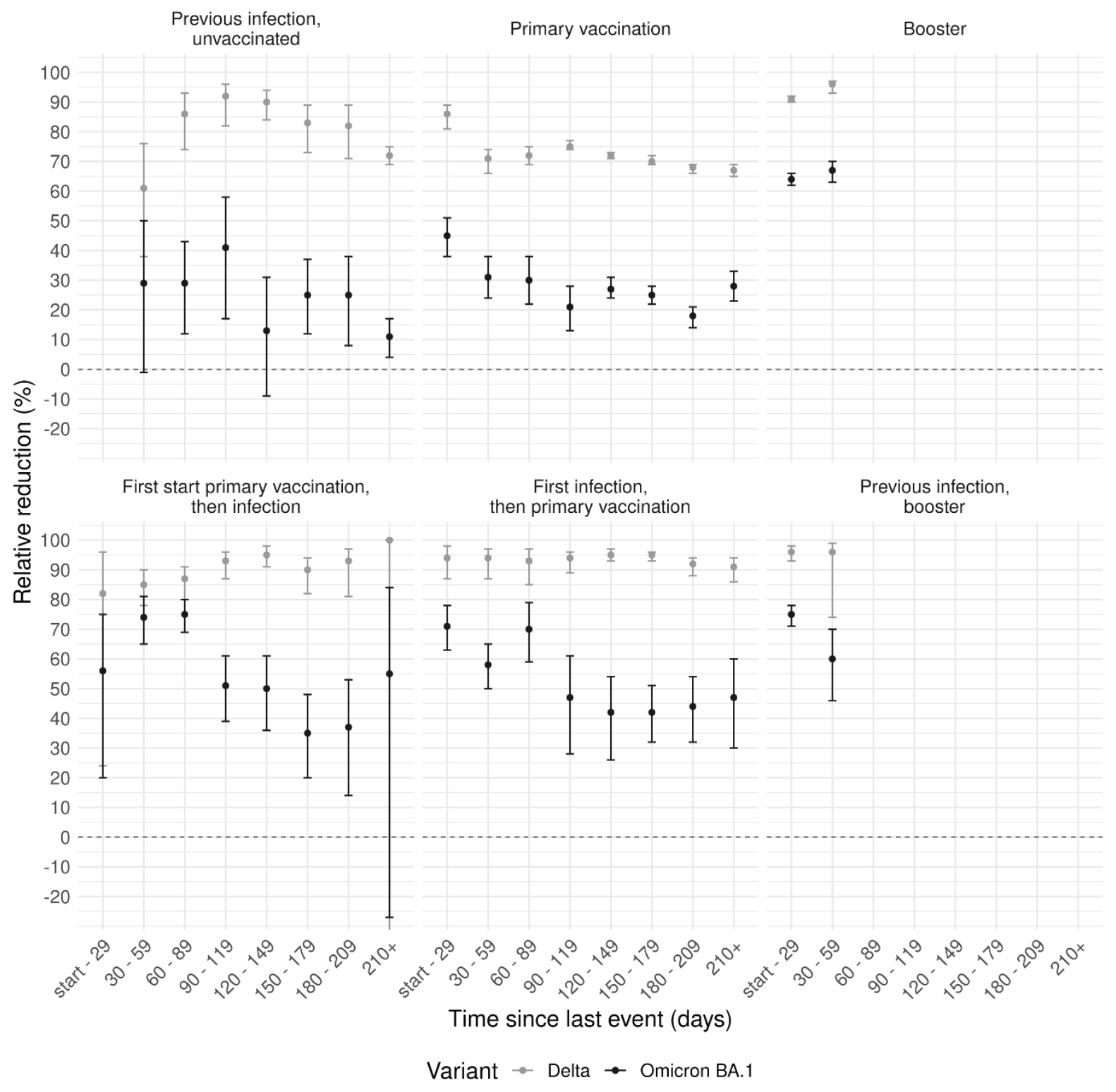

Figure 1. Relative reduction in Delta and Omicron BA.1 infections atter previous infection, primary vaccination, booster vaccination, or combinations of previous infection and vaccination, compared with naïve status $((1-\mathrm{OR}) * 100)$, by time since last event in persons aged 18 and older. 
medRxiv preprint doi: https://doi.org/10.1101/2022.02.06.22270457; this version posted February 8,2022 . The copyright holder for this preprint (which was not certified by peer review) is the author/funder, who has granted medRxiv a license to display the preprint in All rights reserved. No reuse allowed without permission.

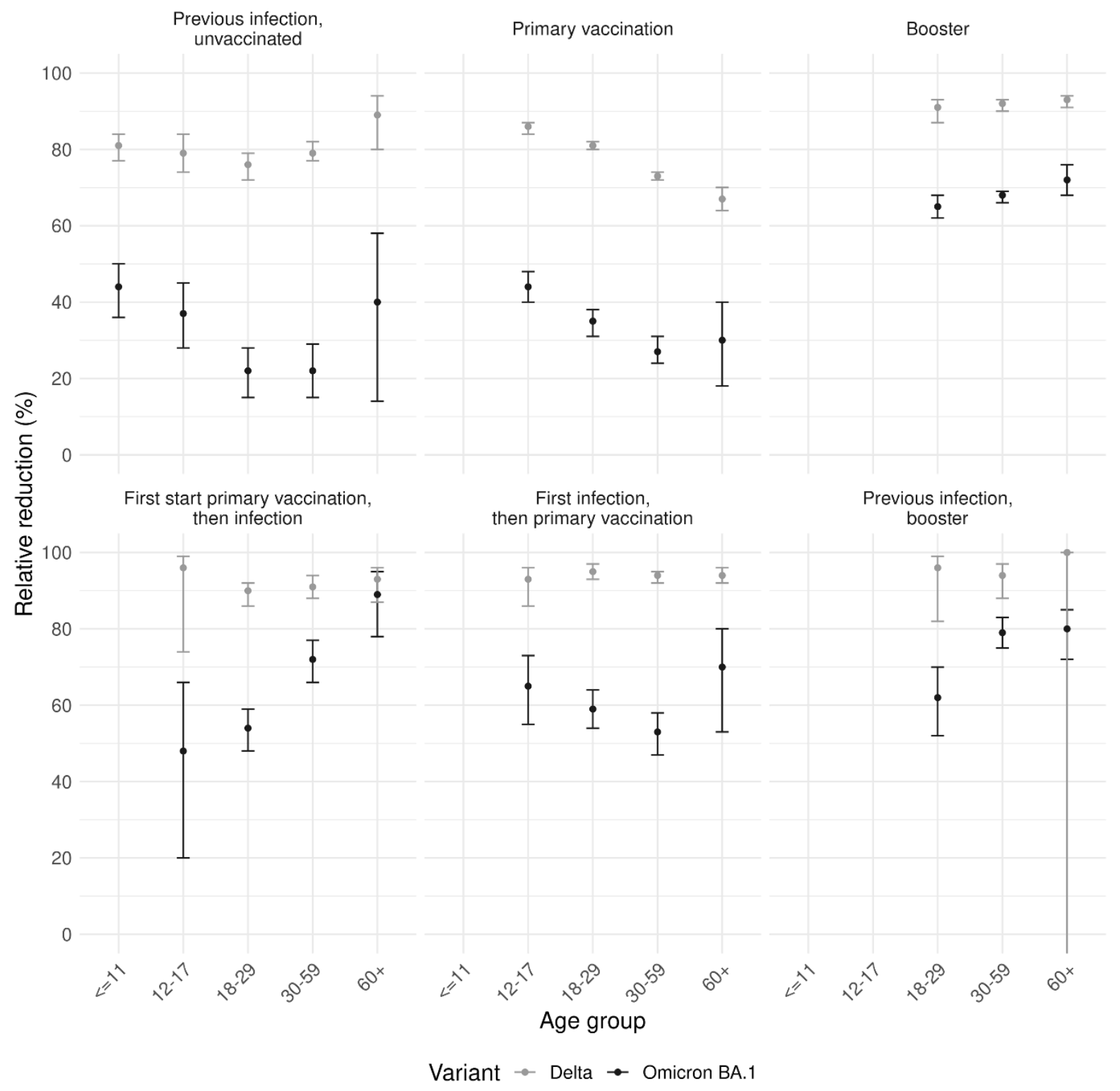

Figure 2. Relative reduction in Delta and Omicron BA.1 infections after previous infection, primary vaccination, booster vaccination, or combination of previous infection and vaccination, compared with naïve status $((1-O R) * 100)$, by age group.

\section{Discussion}

We assessed the protection of previous infection, and primary and booster vaccination with and without previous infection against Omicron BA.1 or Delta infection. Our analyses show a large reduction in protection conferred by previous SARS-CoV-2 infections and/or vaccination against the Omicron BA.1 variant, as compared to the Delta variant. Booster vaccination increased effectiveness against Omicron, at least for the first two months after booster vaccination, but to a lesser extent than against Delta infection, resulting in a much lower booster vaccine effectiveness for Omicron compared with Delta ( 68 vs $93 \%$ among those without known prior infection). The modest vaccine effectiveness against Omicron infection we found is comparable to estimates from other studies [8, 
medRxiv preprint doi: https://doi.org/10.1101/2022.02.06.22270457; this version posted February 8,2022 . The copyright holder for this preprint (which was not certified by peer review) is the author/funder, who has granted medRxiv a license to display the preprint in All rights reserved. No reuse allowed without permission.

13]. The UK showed vaccine effectiveness against Omicron of maximally $20 \%$ at 25 weeks after primary vaccination, which increased to $60-70 \%$ up to nine weeks after booster vaccination [8]. Similar to our findings, others have shown considerable waning of effectiveness of primary vaccination against both Delta and Omicron infection $[8,14,15]$. The UK data showed that also after booster vaccination, effectiveness against Omicron infection decreased quickly over time to $50 \%$ at 10 or more weeks after vaccination [8].

Our results showed loss of protection against Omicron infection conferred by previous infection with a different variant, which is in line with an observed increase in re-infection cases since the emergence of Omicron $[10,16,17]$. In the Netherlands, the percentage of new positive tests that were re-infections rose from around 3\% during the Delta-dominated period to $12-13 \%$ in the first weeks of 2022 [18]. A preprint analyzing reinfections in Qatar found that protection of previous infection in preventing Omicron infection was 62\%, which was considerably lower than protection afforded by previous infection in preventing infection with Delta, but higher than the protective effect in our study [19].

In our study, the combination of both previous infection and primary vaccination provided more protection against Omicron than either of those alone. Highest levels of protection were observed in recently boosted individuals with a previous infection. The estimates for persons with first infection then vaccination and first vaccination then infection were quite comparable, suggesting that the sequence of vaccination and infection did not influence the level of protection. A recent study found broadly neutralizing antibodies against several variants of concern, not including Omicron, in sera from vaccinated plus infected individuals regardless of the sequence of vaccination and infection [20]. Another recent study found that the number of immunizing events (vaccinations and/or infections) correlates with the quality and breadth of the neutralizing antibody response, including against Omicron [21]. Our results are in line with these studies and indicate that reinfections and breakthrough infection during the current Omicron wave could contribute to broader immunity in the population, also against future variants. Of note, in our study the previous infections in persons with first infection then vaccination will likely have been infections by wildtype SARS-CoV-2 or the Alpha variant, while previous infections in persons with first vaccination then infection will likely have been infections by the Delta variant.

In this study, we used data from community testing so this will largely have been persons with mild infections at the time of testing. Vaccine effectiveness against severe COVID-19 is higher than against infection, also for the Omicron variant. A UK study found vaccine effectiveness against hospitalization of $44 \%$ at 25 or more weeks after the second dose, and $90 \%$ shortly after the third dose, decreasing to $75 \%$ after 10-14 weeks after the third dose [8]. These estimates are quite lower than against severe COVID-19 by the Delta variant. However, the risk of a severe disease course after Omicron infection has been shown to be lower than after Delta infection [3-5], which will at least partly compensate for the lower vaccine effectiveness.

Our data has some limitations. Vaccination status is self-reported and may have led to some misclassification, although we do not expect a differential misclassification effect by variant. Because only the number of doses and brand of last dose was reported, booster vaccinations after primary (single dose) vaccination with the Janssen vaccine could not be distinguished from 2-dose primary series. Also, individuals with a previous infection before onset of primary vaccination were given the choice to forego the first dose. This group could also have been misclassified as having received a primary series while the second dose was a booster dose. In around $6.3 \%$ of the Dutch population having received 2 doses the second dose was a booster after a one-dose primary series. This misclassification may have resulted in overestimation of the VE shortly after a primary series. 
medRxiv preprint doi: https://doi.org/10.1101/2022.02.06.22270457; this version posted February 8,2022 . The copyright holder for this preprint (which was not certified by peer review) is the author/funder, who has granted medRxiv a license to display the preprint in All rights reserved. No reuse allowed without permission.

Another source of misclassification is the use of the community testing data to determine previous infection status. A relevant share of previous infections will be missing from this dataset, e.g. because of restrictive testing policy in the early months of the pandemic. For children below the age of 12 , testing was not strongly encouraged for a long time, and the mild and often asymptomatic disease course in this age group will further contribute to a large share of undetected infections. This misclassification will have led to an underestimation of the effect of a previous infection. Further, non-SGTF is not a perfect indicator of Delta infection. At the end of December 2021, the first Omicron BA.2 variant was detected in the random pathogen surveillance in the Netherlands, although until the second week of January 2022 the number of Omicron BA.2 detections was very small compared with the number of Delta detections [2].

In conclusion, we showed that primary vaccination with the current COVID-19 vaccines and preOmicron SARS-CoV-2 infections offer low protection against Omicron BA.1 infection. Booster vaccination increases protection against Omicron BA.1 infection, although to a lesser extent than against Delta. The balance between the lower vaccine effectiveness against infection, transmission and severe COVID-19, as well as the uptake of (booster) vaccination and the reduced disease severity of Omicron infection as compared to Delta will determine the height of the peak in infections and hospitalizations due to Omicron.

\section{References}

1. European Centre for Disease Prevention and Control (ECDC). Assessment of the further emergence and potential impact of the SARS-CoV-2 Omicron variant of concern in the context of ongoing transmission of the Delta variant of concern in the EU/EEA, 18th update. Available from: https://www.ecdc.europa.eu/sites/default/files/documents/covid-19-assessment-furtheremergence-omicron-18th-risk-assessment-december-2021.pdf.

2. National Institute for Public Health and the Environment (RIVM). Variants of the coronavirus SARS-CoV-2. Available from: https://www.rivm.nl/en/coronavirus-covid-19/virus/variants.

3. Davies M-A, Kassanjee R, Rosseau P, Morden E, Johnson L, Solomon W, et al. Outcomes of laboratory-confirmed SARS-CoV-2 infection in the Omicron-driven fourth wave compared with previous waves in the Western Cape Province, South Africa. medRxiv. 2022:2022.01.12.22269148. doi: 10.1101/2022.01.12.22269148.

4. Lewnard JA, Hong VX, Patel MM, Kahn R, Lipsitch M, Tartof SY. Clinical outcomes among patients infected with Omicron (B.1.1.529) SARS-CoV-2 variant in southern California. medRxiv. 2022:2022.01.11.22269045. doi: 10.1101/2022.01.11.22269045.

5. Wolter N, Jassat W, Walaza S, Welch R, Moultrie H, Groome M, et al. Early assessment of the clinical severity of the SARS-CoV-2 omicron variant in South Africa: a data linkage study. Lancet. 2022;399(10323):437-46. Epub 20220119. doi: 10.1016/s0140-6736(22)00017-4. PubMed PMID: 35065011; PubMed Central PMCID: PMCPMC8769664.

6. Netzl A, Tureli S, LeGresley E, Mühlemann B, Wilks SH, Smith DJ. Analysis of SARS-CoV-2 Omicron Neutralization Data up to 2021-12-22. bioRxiv. 2022:2021.12.31.474032. doi: 10.1101/2021.12.31.474032.

7. UK Health Security Agency. SARS-CoV-2 variants of concern and variants under investigation in England: Technical briefing 35. Available from:

https://assets.publishing.service.gov.uk/government/uploads/system/uploads/attachment data/file 11050999/Technical-Briefing-35-28January2022.pdf.

8. UK Health Security Agency. COVID-19 vaccine surveillance report. Week 4. 27 January 2022. Available from:

https://assets.publishing.service.gov.uk/government/uploads/system/uploads/attachment data/file L1050721/Vaccine-surveillance-report-week-4.pdf. 
medRxiv preprint doi: https://doi.org/10.1101/2022.02.06.22270457; this version posted February 8, 2022. The copyright holder for this preprint (which was not certified by peer review) is the author/funder, who has granted medRxiv a license to display the preprint in

All rights reserved. No reuse allowed without permission.

9. Eggink D, Andeweg SP, Vennema H, van Maarseveen N, Vermaas K, Vlaemynck B, et al. Increased risk of infection with SARS-CoV-2 Omicron BA.1 compared with Delta in vaccinated and previously infected individuals, the Netherlands, 22 November 2021 to 19 January 2022. LID 10.2807/1560-7917.ES.2022.27.4.2101196 [doi]. (1560-7917 (Electronic)).

10. Pulliam JRC, van Schalkwyk C, Govender N, von Gottberg A, Cohen C, Groome MJ, et al. Increased risk of SARS-CoV-2 reinfection associated with emergence of the Omicron variant in South Africa. medRxiv. 2021:2021.11.11.21266068. doi: 10.1101/2021.11.11.21266068.

11. National Institute for Public Health and the Environment (RIVM). Figures on the COVID-19 vaccination programme. Available from: https://www.rivm.nl/en/covid-19-vaccination/figuresvaccination-programme.

12. Government of the Netherlands. Coronavirus Dashboard. COVID-19 vaccinations [03 February 2021]. Available from: https://coronadashboard.government.nl/landelijk/vaccinaties. 13. Statens Serum Institut. Covid-19 Gennembruds infektioner og vaccineeffektivitet. Available from: https://files.ssi.dk/covid19/gennembrudsinfektion/rapport/gennembrudsinfektion-covid19uge01-2022-dk30.

14. Buchan SA, Chung H, Brown KA, Austin PC, Fell DB, Gubbay JB, et al. Effectiveness of COVID19 vaccines against Omicron or Delta symptomatic infection and severe outcomes. medRxiv. 2022:2021.12.30.21268565. doi: 10.1101/2021.12.30.21268565.

15. Tseng HF, Ackerson BK, Luo Y, Sy LS, Talarico CA, Tian Y, et al. Effectiveness of mRNA-1273 against SARS-CoV-2 omicron and delta variants. medRxiv. 2022:2022.01.07.22268919. doi: 10.1101/2022.01.07.22268919.

16. Neil Ferguson, Azra Ghani, Anne Cori et al. Growth, population distribution and immune escape of the Omicron in England. Imperial College London, 16 December 2021. Report No.

17. Statens Serum Institut. Reinfektioner indgår nu i Statens Serum Instituts daglige overvågning. Available from: https://www.ssi.dk/aktuelt/nyheder/2021/reinfektioner-indgar-nu-i-statens-seruminstituts-daglige-overvagning.

18. National Institute for Public Health and the Environment (RIVM). 200 duizend mensen testten positief in 1 week. Available from: https://www.rivm.nl/nieuws/200-duizend-mensentestten-positief-in-1-week.

19. Altarawneh $\mathrm{H}$, Chemaitelly H, Tang P, Hasan MR, Qassim S, Ayoub HH, et al. Protection afforded by prior infection against SARS-CoV-2 reinfection with the Omicron variant. medRxiv. 2022:2022.01.05.22268782. doi: 10.1101/2022.01.05.22268782.

20. Bates TA, McBride SK, Leier HC, Guzman G, Lyski ZL, Schoen D, et al. Vaccination before or after SARS-CoV-2 infection leads to robust humoral response and antibodies that effectively neutralize variants. Sci Immunol. 2022:eabn8014. Epub 20220125. doi:

10.1126/sciimmunol.abn8014. PubMed PMID: 35076258.

21. Walls AC, Sprouse KR, Bowen JE, Joshi A, Franko N, Navarro MJ, et al. SARS-CoV-2 breakthrough infections elicit potent, broad and durable neutralizing antibody responses. Cell. 2022. doi: https://doi.org/10.1016/i.cell.2022.01.011.

\section{Acknowledgements}

Members of the RIVM COVID-19 surveillance and epidemiology team

Agnetha Hofhuis, Anne Teirlinck, Anne-Wil Valk, Bronke Boudewijns , Carolien Verstraten, Claudia Laarman, Femke Jongenotter, Fleur Petit, Guido Willekens, Irene Veldhuijzen, Jan Polman, Jan van de Kassteele, Janneke van Heereveld, Janneke Heijne, Kirsten Bulsink, Liselotte van Asten, Liz Jenniskens, Lieke Wielders, Loes Soetens, Maarten Mulder, Maarten Schipper, Marit de Lange, Naomi Smorenburg, Nienke Neppelenbroek, Patrick van den Berg, Priscila de Oliveira Bressane Lima, Rolina van Gaalen, Senna van lersel, Siméon de Bruijn, Stijn Andeweg, Sjoerd Wierenga, Susan 
medRxiv preprint doi: https://doi.org/10.1101/2022.02.06.22270457; this version posted February $8,2022$. The copyright holder for this preprint (which was not certified by peer review) is the author/funder, who has granted medRxiv a license to display the preprint in All rights reserved. No reuse allowed without permission.

Lanooij, Sylvia Keijser, Tara Smit, Thomas Dalhuisen, Don Klinkenberg, Jantien Backer, Pieter de Boer, Scott McDonald, Amber Maxwell, Annabel Niessen, Brechje de Gier, Danytza Berry, Daphne van Wees, Dimphey van Meijeren, Henri van Werkhoven, Eric Vos, Frederika Dijkstra, Jeanet Kemmeren, Kylie Ainslie, Marjolein Kooijman, Mirjam Knol, Timor Faber, Albert Jan van Hoek, Birgit van Benthem, Eveline Geubbels, Hester de Melker, Jacco Wallinga, Rianne van Gageldonk-Lafeber, Susan Hahne, Susan van den Hof 
medRxiv preprint doi: https://doi.org/10.1101/2022.02.06.22270457; this version posted February $8,2022$. The copyright holder for this preprint (which was not certified by peer review) is the author/funder, who has granted medRxiv a license to display the preprint in perpetuity.

All rights reserved. No reuse allowed without permission.

\section{Supplementary material}

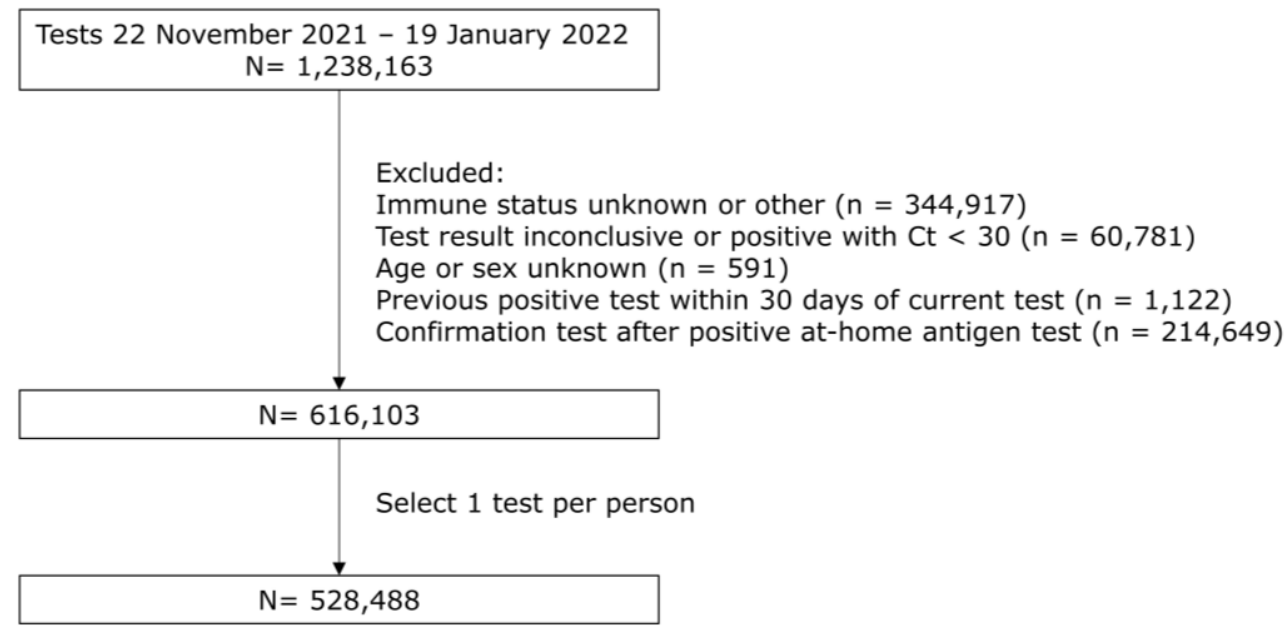

Figure S1. Flowchart of data selection 
medRxiv preprint doi: https://doi.org/10.1101/2022.02.06.22270457; this version posted February $8,2022$. The copyright holder for this preprint (which was not certified by peer review) is the author/funder, who has granted medRxiv a license to display the preprint in

perpetuity.
All rights reserved. No reuse allowed without permission.

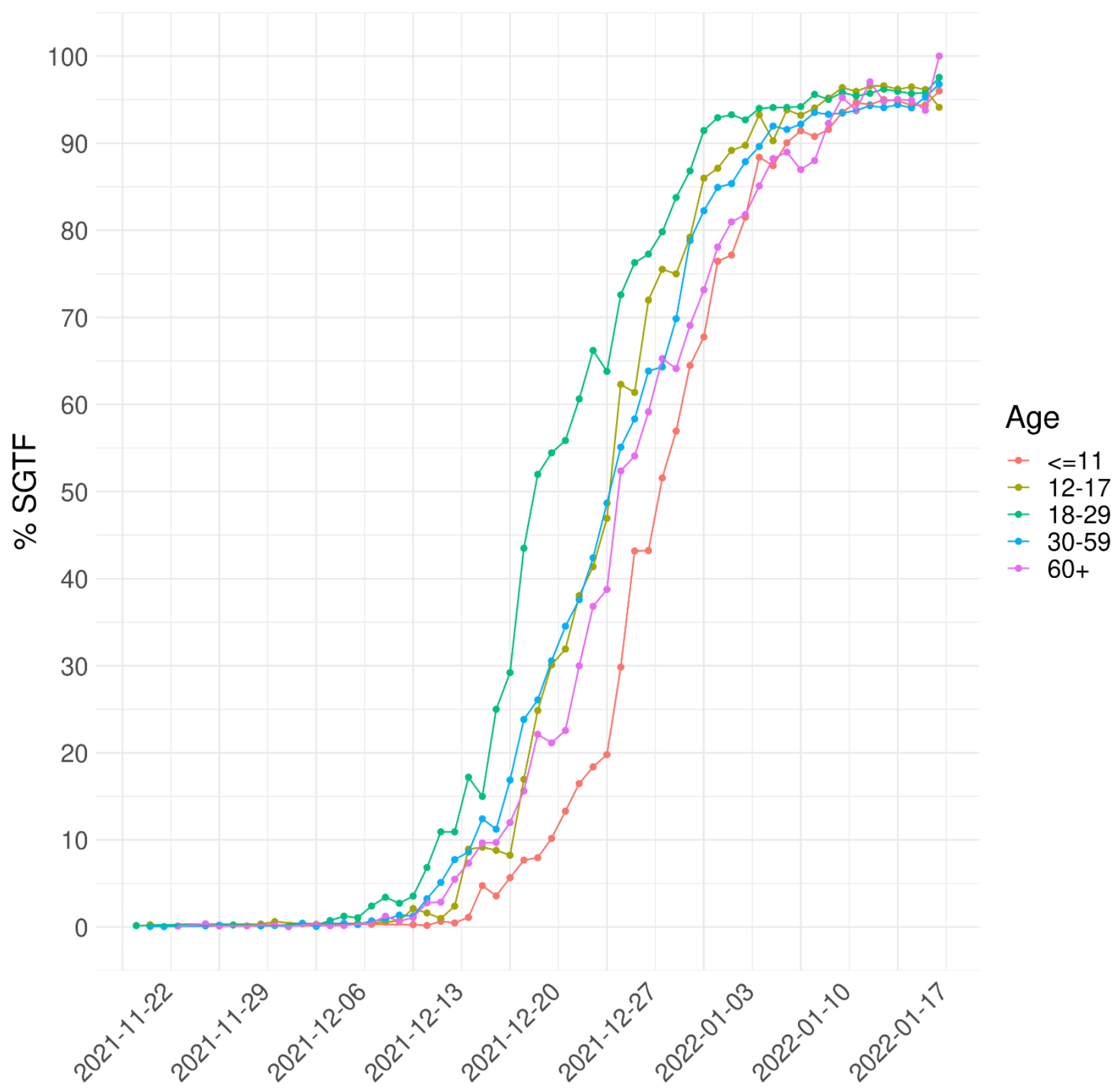

Figure S2. Proportion of SGTF among positive SARS-CoV-2 cases by age group, the Netherlands, 22 November 2021 - 19 January 2022, $n=282,030$. 